\title{
An intensive care approach to posterior reversible encephalopathy syndrome (PRES): An analysis of 7 cases
}

\author{
İsmail Demirel' ${ }^{1}$ Burçin Salih Kavak², Ayşe B. Özer', Mustafa K. Bayar', Ömer L. Erhan ${ }^{1}$ \\ ${ }^{1}$ Department of Anesthesiology and Reanimation, Furat University Faculty of Medicine, Elaziğ, Turkey \\ ${ }^{2}$ Department of Obstetric and Gynecology, Firat University Faculty of Medicine, Elazığ, Turkey
}

\section{Abstract}

Objective: The aim of this study was to retrospectively evaluate the intensive care unit treatments applied to obstetrics patients with a diagnosis of posterior reversible encephalopathy syndrome (PRES).

Material and Methods: The cases of 7 pregnant patients who had been diagnosed with PRES between July 2011 and July 2013 were retrospectively reviewed. The patients' clinical data, brain magnetic resonance imaging (MRI) images before and after treatment, and neuropsychological tests were evaluated.

Results: Five out of 7 patients had eclampsia, 1 patient had severe preeclampsia, and 1 patient developed HELLP syndrome secondary to PRES. Calcium channel blockers and $\beta$-blockers were used as antihypertensive treatment. All patients were treated with parenteral magnesium sulfate. In addition, sodium thiopental was given to control sedation and convulsions in all patients except 1 . The neurological and radiological findings of all cases treated in the intensive care unit improved.

Conclusion: Posterior reversible encephalopathy syndrome is a clinical condition with a multifactorial etiology and can result in different clinical findings. Radiological imaging techniques can be used for the diagnosis of PRES. Pregnancy and the postpartum period often lead to this syndrome. In some cases, PRES can cause irreversible neurological deficits or death. For patients with severe radiological findings, early diagnosis and thiopental infusion, in addition to treatment with antihypertensive agents and magnesium sulfate, may lead to quicker and more effective recovery from clinical manifestations. We suggest supplementation of standard treatment with early thiopental infusion. (J Turk Ger Gynecol Assoc 2014; 15: 217-21)

Key words: PRES, intensive care unit, obstetrics patient

Received: 12 May, $2014 \quad$ Accepted: 19 September, 2014

\section{Introduction}

Posterior reversible encephalopathy syndrome (PRES) is a clinical entity characterized by temporary neurological symptoms, including acute headache, altered mental status, vision loss, and coma. Among the etiological factors associated with PRES are such diseases as hypertensive encephalopathy, preeclampsia/eclampsia/HELLP syndrome, immunosuppressive/cytotoxic drugs, acute or chronic renal disease, thrombotic thrombocytopenic purpura/hemolytic uremic syndrome, high-dose steroid therapy, liver failure/transplantation, endocrine dysfunction, hypercalcemia/hyperparathyroidism, bone marrow transplantation, massive blood transfusion/erythropoietin therapy, and porphyria $(1,2)$. Neuroimaging studies (MRI) in patients with PRES showed posterior cerebral edema (3-5). Following elimination of PRES-triggering factors and initiation of appropriate treatment, clinical and radiological findings usually resolve (6-8).

Most PRES cases occur concomitantly with acute or subacute neurological signs associated with convulsions. Usually, convulsions are initially local and then become generalized.
Sometimes, seizures cause status epilepticus. In addition, changes in behavior and consciousness -ranging from somnolence and lethargy to stupor and coma- can occur. Moreover, various visual impairments, including hemianopsia, blurred vision, and cortical blindness, can be observed (1-4).

Patients with PRES are treated via provision of hemodynamic stability and hydration (intravenous crystalloid-colloids), maintenance of adequate arterial oxygen pressure, and improvement of electrolyte disturbances and coagulopathy (9). In patients with pulmonary aspiration, pulmonary edema, and hypoxemia, endotracheal intubation and mechanical ventilation are performed to maintain adequate oxygenation, while in those with impaired cardiac function, a central venous catheter may be required $(10,11)$. Although PRES is reversible when diagnosed and treated in a timely fashion, it can lead to neurological complications, including permanent brain damage and chronic epilepsy, when diagnosed at later stages $(1,2)$. Herein, we present 7 pregnant patients diagnosed with PRES, based on clinical and radiological findings, who were treated in our intensive care unit during a 2-year period. Patient 
records were retrospectively reviewed, and the medical treatment outcomes were evaluated in light of the literature.

\section{Material and Methods}

The study protocol was approved by the ethics committee. The clinical records of 7 patients (aged 20-36 years) who were diagnosed with PRES and treated at the intensive care unit of Frrat University Medical School Hospital between July 2011 and July 2013 were retrospectively reviewed. The clinical diagnosis in all patients was made as previously described. Preeclampsia was diagnosed and classified according to American College of Obstetricians and Gynecologists (ACOG) criteria. Severe preeclampsia was defined as blood pressure $\geq 160 / 110 \mathrm{~mm} \mathrm{Hg}$, with either a urine dipstick showing $3+$ or $4+$ in a random urine sample or proteinuria $\geq 5.0 \mathrm{~g}$ during $24 \mathrm{~h}$. Other evidence of severe disease included elevated serum creatinine, eclampsia, pulmonary edema, oliguria ( $<500 \mathrm{~mL} 24 / \mathrm{h})$, fetal growth restriction, oligohydramnios, and symptoms indicative of significant end-organ involvement (headache, visual disturbance, and epigastric or right upper quadrant pain) (12). HELLP syndrome was defined based on the presence of hemolysis (serum LDH $>600$ $\mathrm{IU} / \mathrm{L}$, bilirubin $>1.2 \mathrm{mg} / \mathrm{dL}$, and the presence of schistocytes in peripheral blood), elevated liver enzymes (serum ALT and/or AST $>70$ IU/L), and thrombocytopenia (platelet count $<100,000$ $\mathrm{mm}^{-3}$ ) after 20 weeks of gestation (13).

Cranial MRI (Signa Excite 1.5 T system (GE Healthcare, Milwaukee, WI, USA) using an 8-channel neuro-vascular head coil was performed in all patients after the onset of symptoms. Neuroimaging of the brain was performed via spin-echo T2-weighted (TR/TE/number of excitations $=2880 / 126 / 2$ ), spinecho T1-weighted (460/14/2), and T2-FLAIR-weighted MRI (TR/ $\mathrm{TI} / \mathrm{TE} /$ number of excitations $=8800 / 2000 / 126 / 2$ ) in the axial, sagittal, and coronal planes with $5-\mathrm{mm}$ slice thickness. In addition, cranial MRI and detailed neuropsychological test (EMG, EEG, NCV, VEP-BERA, and TCD) findings obtained 1 month posttreatment were evaluated in each patient.

\section{Results}

The clinical and radiological findings are summarized in the Table 1 . The mean age of the patients was $26.85 \pm 7.10$ years

Table 1. The clinical and radiologic findings and treatment in the PRES patients

\begin{tabular}{|c|c|c|c|c|c|c|c|c|c|c|}
\hline Patients & $\begin{array}{c}\text { Age } \\
\text { (years) }\end{array}$ & $\begin{array}{c}\text { G/P/A } \\
\text { (n) }\end{array}$ & $\begin{array}{l}\text { Clinical } \\
\text { diagnosis }\end{array}$ & $\begin{array}{c}\text { Gestational } \\
\text { age } \\
\text { (weeks) }\end{array}$ & $\begin{array}{l}\text { Neurological } \\
\text { symptoms }\end{array}$ & $\begin{array}{c}\text { Status } \\
\text { epilepticus }\end{array}$ & $\begin{array}{c}\text { Location } \\
\text { of T1-Hypo/ } \\
\text { T2-Hyper } \\
\text { intense } \\
\text { abnormalities }\end{array}$ & $\begin{array}{c}\text { ICU } \\
\text { therapy }\end{array}$ & $\begin{array}{l}\text { Time to } \\
\text { remission } \\
\text { (d) }\end{array}$ & $\begin{array}{c}\text { Time to } \\
\text { MV } \\
\text { (d) }\end{array}$ \\
\hline 1 & 21 & $1 / 0 / 0$ & Eclampsia & 31 & $\begin{array}{l}\text { Convulsions, } \\
\text { Confusion, } \\
\text { Headache } \\
\text { Amlodipia }\end{array}$ & No & $\begin{array}{l}\text { Bilateral } \\
\text { Occipital }\end{array}$ & $\begin{array}{l}\text { Thiopental, } \\
\text { Esmolol, } \\
\text { Magnesium }\end{array}$ & 4 & 1 \\
\hline 2 & 20 & $1 / 0 / 0$ & Eclampsia & 39 & $\begin{array}{c}\text { Convulsions, } \\
\text { Headache }\end{array}$ & Yes & $\begin{array}{l}\text { Bilateral } \\
\text { Occipital }\end{array}$ & $\begin{array}{l}\text { Thiopental, } \\
\text { Esmolol, } \\
\text { Magnesium, } \\
\text { Amlodipine }\end{array}$ & 4 & 2 \\
\hline 3 & 33 & $4 / 3 / 0$ & $\begin{array}{c}\text { HELLP } \\
\text { Syndrome }\end{array}$ & 26 & $\begin{array}{c}\text { Convulsions, } \\
\text { Headache }\end{array}$ & No & $\begin{array}{l}\text { Left Basal } \\
\text { Ganglia, } \\
\text { Cerebellum }\end{array}$ & $\begin{array}{l}\text { Thiopental, } \\
\text { Esmolol, } \\
\text { Magnesium, } \\
\text { Amlodipine }\end{array}$ & 5 & 3 \\
\hline 4 & 34 & $1 / 0 / 0$ & Eclampsia & 36 & $\begin{array}{l}\text { Convulsions, } \\
\text { Headache }\end{array}$ & Yes & $\begin{array}{c}\text { Bilateral } \\
\text { Occipital } \\
\text { Cerebellum }\end{array}$ & $\begin{array}{l}\text { Thiopental, } \\
\text { Esmolol, } \\
\text { Magnesium, } \\
\text { Amlodipine }\end{array}$ & 2 & 1 \\
\hline 5 & 21 & $1 / 0 / 0$ & Eclampsia & 31 & $\begin{array}{c}\text { Convulsions, } \\
\text { Headache }\end{array}$ & No & $\begin{array}{c}\text { Bilateral } \\
\text { Parieto- } \\
\text { Occipital and } \\
\text { Bilateral } \\
\text { Basal Ganglia }\end{array}$ & $\begin{array}{l}\text { Thiopental, } \\
\text { Esmolol, } \\
\text { Magnesium, } \\
\text { Amlodipine }\end{array}$ & 4 & 2 \\
\hline 6 & 23 & $2 / 1 / 0$ & $\begin{array}{c}\text { Severe } \\
\text { Pre- } \\
\text { eclampsia }\end{array}$ & 36 & Headache & No & $\begin{array}{l}\text { Bilateral } \\
\text { Occipital }\end{array}$ & $\begin{array}{c}\text { Esmolol, } \\
\text { Magnesium, } \\
\text { Amlodipine }\end{array}$ & 2 & $\varnothing$ \\
\hline 7 & 36 & $3 / 0 / 2$ & Eclampsia & 31 & $\begin{array}{l}\text { Headache, } \\
\text { Convulsions, } \\
\text { Blurred } \\
\text { Vision }\end{array}$ & Yes & $\begin{array}{l}\text { Bilateral } \\
\text { Cerebellar, } \\
\text { Frontal, } \\
\text { Parietal, } \\
\text { Frontal, } \\
\text { Occipital }\end{array}$ & $\begin{array}{l}\text { Thiopental, } \\
\text { Esmolol, } \\
\text { Magnesium, } \\
\text { Amlodipine }\end{array}$ & 15 & 10 \\
\hline
\end{tabular}


(range: 20-36 years). The etiology of PRES was as follows: eclampsia: $n=5$ (72\%); severe preeclampsia: $n=1$ (14\%); and HELLP syndrome: $n=1$ (14\%). Among the patients, hypertension (160-210/110-130 mm Hg), headache, and altered consciousness (ranging from confusion to coma) were observed. In all, 1 patient had blurred vision (14\%) and 3 had status epilepticus (43\%). Cranial MRI showed edema localized mainly to the posterior cerebral region. In addition, the cerebellum; basal ganglia; and frontal, parietal, and occipital lobes were affected to varying degrees (Figure 1).

Calcium channel blockers (amlodipine (Norvasc; Pfizer, İstanbul, Turkey) $10 \mathrm{mg} / \mathrm{d}$, enteral) and $\beta$-blockers (esmolol (Brevibloc, Eczacıbaşı-Baxter, İstanbul, Turkey) 50-200 mg/ $\mathrm{kg} / \mathrm{min}$, parenteral) were administered to treat hypertension. Parenteral magnesium sulfate (Osel Drug, İstanbul, Turkey) (4-6 g 20/min IV and 1-2 g/h infusion) was administered to all patients. Moreover, all patients but 1 (case 6) were treated with thiopental sodium (I.E. Ulagay, İstanbul, Turkey) $(2-4 \mathrm{mg} / \mathrm{kg}$ bolus, followed by infusion of $3-5 \mathrm{mg} / \mathrm{kg} / \mathrm{h}$ for $24-48 \mathrm{~h}$ ) to control sedation and convulsions (Table 1 ). In total, 5 patients received mechanical ventilation support for $1-3 \mathrm{~d}, 1$ patient required mechanical ventilation for $10 \mathrm{~d}$ (SIMV, f:12/min; FiO2: 40, TV: 7 $\mathrm{mL} / \mathrm{kg}$, PEEP: $5 \mathrm{~cm} \mathrm{H} 2 \mathrm{O}, \mathrm{I} / \mathrm{E}: 1 / 2$ ), and 1 patient did not require mechanical ventilator support.

All patients but 1 improved neurologically 2-5 d after PRES was diagnosed. The patient who required mechanical ventilator support for $10 \mathrm{~d}$ regained consciousness on $\mathrm{d} 10$; however, she had speech impairment that lasted $15 \mathrm{~d}$ and improved at the end of the first month. After discontinuing mechanical ventilation, all patients were given parenteral magnesium sulfate. The magnesium level in each patient was monitored and maintained in the therapeutic range (4.8-8.4 $\mathrm{mEq} / \mathrm{L})$, and deep tendon reflexes, respiratory rate, and urine output were observed hourly. Patients whose general condition improved were transferred to the obstetrics and gynecology clinic to continue their treatment. Cranial MRI findings 1 month later were normal (Figure 2). None of the patients had intracranial pathologies, such as fatal subarachnoid hemorrhage due to negative results. Long-term evaluation ( $>1$ year) was possible in 3 of the patients, and neuropsychological dysfunction was not observed.

\section{Discussion}

In the present study, the records of 7 pregnant women who were diagnosed with PRES, based on clinical and neuroimaging findings, and treated in the anesthesia intensive care unit of Firat University Medical School Hospital between July 2011 and July 2013 were retrospectively reviewed. PRES was first described by Hinchey (1) as a sudden increase in blood pressure due to a defect in the autoregulation of posterior circulation that causes clinical symptoms, including headache, generalized seizures, visual disturbances, lethargy, confusion, stupor, changes in mental status, and focal neurological signs. The diagnosis of PRES is made based on clinical and radiological findings (1).

All patients in the present study were diagnosed with PRES based on clinical and radiological findings and had pregnancy- related preeclampsia and/or HELLP syndrome. In addition, all but 1 of the patients had generalized seizures, and 3 patients had status epilepticus. Moreover, 1 patient had blurred vision and speech impairment that lasted $15 \mathrm{~d}$. One patient that was diagnosed with PRES based on radiological findings (hyperintensity in T2-weighted sequences of the bilateral occipital region) had only headache as a neurological symptom, whereas the other patients had widespread neurological symptoms. Cranial CT can be used to diagnose hypodense lesions of posterior encephalopathy; however, MRI is the gold standard for diagnosing PRES (1-3). Currently, PRES is diagnosed

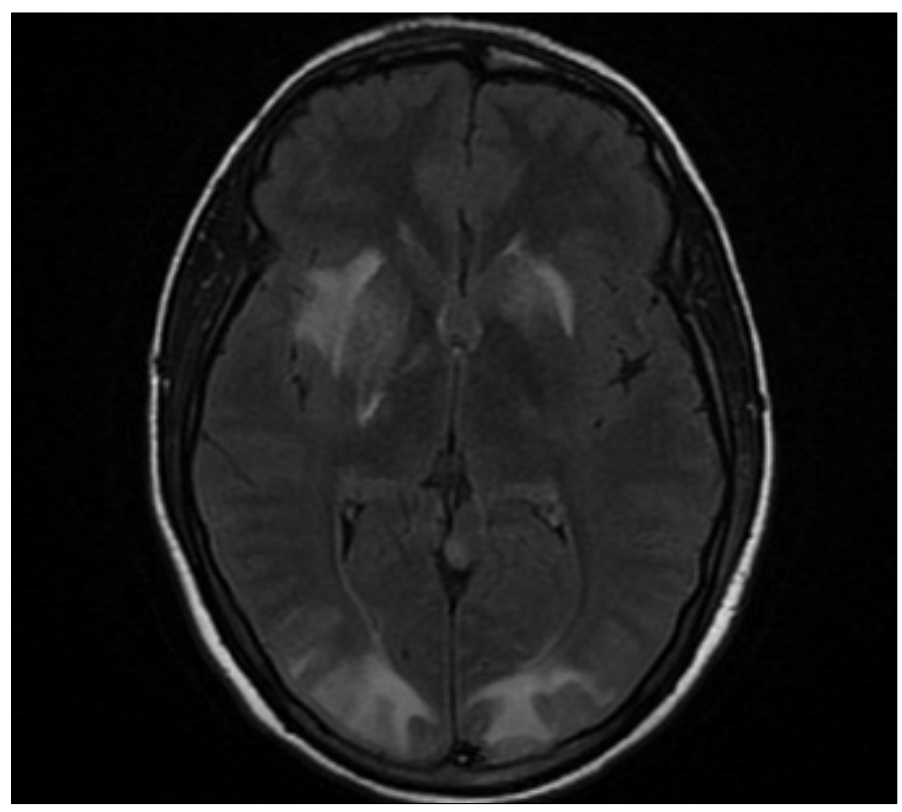

Figure 1. T2-weighted cranial MRI sequences showing multiple, hyperintense areas bilaterally in the parietal-occipital regions and basal ganglia

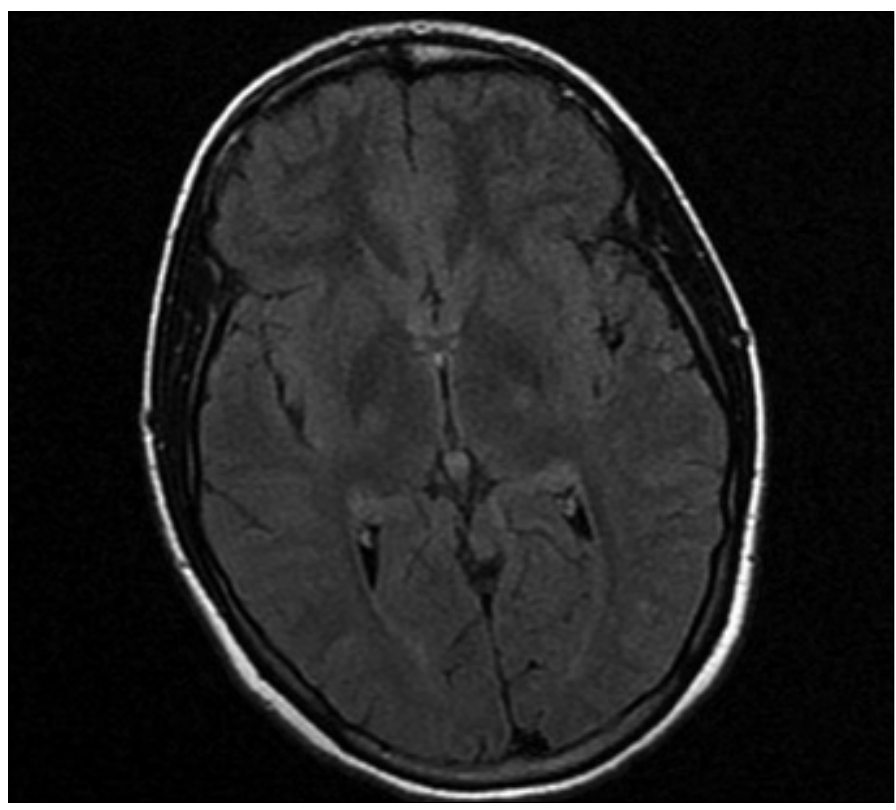

Figure 2. MRI scan obtained 1 month post-treatment in patient 5 
more frequently than in the past due to the ubiquity of MRI. During the acute phase of PRES, hyperintensity is observed in T2-weighted MRI sequences, and iso-hypointensity is observed in T1-weighted sequences of gray and white matter. PRES primarily affects the parietal-occipital lobe; however, the cerebellar hemispheres, basal ganglion, frontal lobes, and brainstem are also frequently affected $(1,2,14)$. Diffusion-weighted MRI is more sensitive to changes in the distribution of brain fluid, can detect edema in white matter during early-stage PRES, and is more reliable for differentiating between vasogenic edema and cytotoxic edema in PRES patients $(3,14)$. In patients with clinical symptoms suggestive of PRES, T2-weighted MRI sequences showed hyperintensity anomalies, especially in the occipital, parietal, and frontal lobes; cerebellum; and basal ganglia.

The pathogenesis of PRES is not fully understood, but it is likely to be associated with endothelial damage and disruption of cerebral autoregulation. Accordingly, edema that is reversible has been suggested to occur in PRES due to impaired autoregulation associated with hyperperfusion and blood-brain barrier disruption without infarction (15-18). When increased systemic blood pressure exceeds cerebral autoregulatory mechanisms, it increases the permeability of the blood-brain barrier, thereby causing extravasation of fluid and blood into the brain parenchyma $(6,19)$. Elevated blood pressure leads to focal dilation in cerebral blood vessels, exceeding the upper limit of autoregulation; consequently, both vasodilation and vasoconstriction develop in these regions $(20,21)$. Another theory of the development of PRES is that cerebral artery spasms, ischemia, and cytotoxic edema are caused by acute hypertension due to a decrease in cerebral blood flow (9).

With the appropriate treatment, most PRES patients completely recover within a few weeks (1). Delays in the diagnosis and treatment can negatively affect brain tissue, resulting in permanent neurological damage $(5,22-25)$. Sometimes, even with appropriate treatment, full recovery may not be achieved (26-28). In particular, ischemia can complicate the clinical picture, whether or not posterior encephalopathy with vasospasm and infarction are present (29). Full clinical remission was achieved in 2-5 $\mathrm{d}$ in 6 of the 7 presented patients, and MRI scans obtained 1 month later indicated that radiological remission was achieved in all patients. The intensive care process was delayed in 1 patient in the present study; she received mechanical ventilation support for $10 \mathrm{~d}$, remission was delayed for up to $15 \mathrm{~d}$, and her speech impairment persisted, even after she regained consciousness. This patient had the most common radiological involvement.

If elevated systemic blood pressure is left untreated, it can cause the development of or aggravation of cerebral edema. In such patients, mean arterial blood pressure should be maintained at 105-125 mm Hg. Nicardipine and labetalol are usually the firstchoice drugs for the treatment of hypertension. Fenoldopam mesylate is a selective dopamine-1 agonist that can also prevent renal failure. Nitroglycerin is also frequently used in such patients but was reported to aggravate brain edema by causing vasodilation in the brain (30). Sodium nitroprusside, hydralazine, diazoxide, and nimodipine, which is reported to have neuroprotective effects, may also be useful for lowering blood pressure $(31,32)$.
Esmolol (a $\beta$-1 selective adrenoceptor antagonist) was recently reported to potentially inhibit an increase in catecholamines and to have neuroprotective effects by causing changes in the immune system (33). In the present study, parenteral esmolol was administered in addition to an enteral calcium channel blocker (amlodipine) to all 7 PRES patients in order to maintain their mean arterial pressure at $110 \mathrm{~mm} \mathrm{Hg}$.

Magnesium sulfate, propofol, benzodiazepines, phenytoin, barbiturates, and fosphenytoin can be used to treat refractory status epilepticus in pregnant women. In addition to general systemic supportive care, magnesium sulfate is considered to be the mainstay of refractory status epilepticus treatment in pregnant women. Magnesium sulfate increases vasodilation, thus decreasing calcium-dependent vasoconstriction and increasing cerebral blood flow, which prevents ischemic attacks that cause coma $(34,35)$. Patients with refractory status epilepticus are usually treated with continuous infusion of midazolam, propofol, or barbiturates (36). In the present study, patients with generalized convulsions or status epilepticus were treated in the intensive care unit via endotracheal intubation, followed by thiopental infusion $(2-4-\mathrm{mg} / \mathrm{kg}$ bolus followed by $3-5 \mathrm{mg} / \mathrm{kg} / \mathrm{h}$ infusion for a period of 24-48 h) and mechanical ventilation support. The duration of mechanical ventilator support in the present study's patients was determined according to the severity of the clinical and radiological findings. In addition, after discontinuation of mechanical ventilation, patients were given a magnesium sulfate infusion (monitored to be in the therapeutic range of $4.8-8.4 \mathrm{mEq} / \mathrm{L}$ ) for $1 \mathrm{~d}$.

In conclusion, PRES is a clinical condition with a multifactorial etiology, is characterized by varying clinical symptoms, and is diagnosed via radiological imaging techniques. PRES can be diagnosed clinically and radiologically in cases of a sudden increase in blood pressure and consequent neurological conditions, such as headache, generalized seizures, visual disturbances, lethargy, confusion, stupor, and changes in mental status caused by the disruption of autoregulation of posterior circulation. We think that timely supplementation of thiopental infusion to antihypertensive and magnesium sulfate treatment can improve the clinical status faster and more efficiently in patients diagnosed with PRES who experience generalized seizures.

Ethics Committee Approval: Ethics committee approval was received for this study from the ethics committee of noninvasive studies.

Informed Consent: N/A.

Peer-review: Externally peer-reviewed.

Author Contributions: Concept - I.D., B.S.K., A.B.Ö.; Design - I.D., B.S.K., A.B.Ö.; Supervision - I.D., B.S.K., A.B.Ö., M.K.B., Ö.L.E.; Resource I.D., B.S.K., A.B.Ö., M.K.B., Ö.L.E.; Materials - İ.D., B.S.K., A.B.Ö.; Data Collection\&/or Processing - I.D., B.S.K., A.B.Ö.; Analysis\&/or Interpretation - I.D., B.S.K., A.B.Ö., M.K.B.; Literature Search - I.D., B.S.K., A.B.Ö., Ö.L.E.; Writing - I.D., B.S.K., A.B.Ö.; Critical Reviews - I.D., B.S.K., A.B.Ö., M.K.B., Ö.L.E.

Conflict of Interest: No conflict of interest was declared by the authors.

Financial Disclosure: The authors declared that this study has received no financial support. 


\section{References}

1. Hinchey J, Chaves C, Appignani B, Breen J, Pao L, Wang A, et al. A reversible posterior encephalopathy syndrome. N Engl J Med 1996; 334: 494-500. [CrossRef]

2. Kwon S, Koo J, Lee S. Clinical spectrum of reversible posterior leukoencephalopathy syndrome. Pediatr Neurol 2001; 24: 361-4. [CrossRef]

3. Erbai M, Dost B, Öztürk Ö, İskender A, Demiraran Y. Twin pregnancy with posterior reversible encephalopathy syndrome and anesthesia management. J Anesth 2012; 20: 237-40.

4. Casey SO, Sampaio RC, Michel E, Truwit CL. Posterior reversible encephalopathy syndrome: utility of fluid-attenuated inversion recovery MR imaging in the detection of cortical and subcortical lesions. AJNR Am J Neuroradiol 2000; 21: 1199-206.

5. Servillo G, Striano P, Striano S, Tortora F, De Robertis E, Rossano $F$, et al. Posterior reversible encephalopathy syndrome (PRES) in obstetric critically ill patients. Intensive Care Med 2003; 29: 2323-6. [CrossRef]

6. Pavlakis SG, Frank Y, Kalina P, Chandra M, Lu D. Occipital-parietal encephalopathy: A new name for an old syndrome. Pediatr Neurol 1997; 16: 145-8. [CrossRef]

7. Tarım E, Giray S. Posterior Reversible Encephalopathy Syndrome (PRES) in the Differential Diagnosis of Eclampsia: Case Report. Turkiye Klinikleri J Gynecol Obst 2011; 21: 213-5.

8. Maramattom BV, Zaldivar RA, Glynn SM, Eggers SD, Wijdicks EF. Acute intermittent porphyria presenting as a diffuse encephalopathy. Ann Neurol 2005; 57: 581-4. [CrossRef]

9. Weidauer S, Gaa J, Sitzer M, Hefner R, Lanfermann H, Zanella FE. Posterior encephalopathy with vasospasm: MRI and angiography. $\mathrm{J}$ Neurol 2003; 45: 869-76.

10. Andrews P, Azoulay E, Antonelli M, Brochard L, Brun-Buisson C, Dobb G, et al. Year in review in intensive care medicine, 2005. II. Infection and sepsis, ventilator-associated pneumonia, ethics, haematology and haemostasis, ICU organisation and scoring, brain injury. Intensive Care Med 2006; 32: 380-90. [CrossRef]

11. Andrews P, Azoulay E, Antonelli M, Brochard L, Brun-Buisson C, Dobb $\mathrm{G}$, et al. Year in review in intensive care medicine, 2004. III. Outcome, ICU organisation, scoring, quality of life, ethics, psychological problems and communication in the ICU, immunity and hemodynamics during sepsis, pediatric and neonatal critical care, experimental studies. Intensive Care Med 2005; 31: 356-72. [CrossRef]

12. ACOG Committee on Obstetric Practice. ACOG practice bulletin. Diagnosis and management of preeclampsia and eclampsia. Number 33, January 2002. American College of Obstetricians and Gynecologists. Int J Gynaecol Obstet 2002; 77: 67-75.

13. Barton JR, Sibai BM. Diagnosis and management of hemolysis, elevated liver enzymes, and low platelets syndrome. Clin Perinatol 2004; 31: 807-33. [CrossRef]

14. Mascalchi M, Filippi M, Floris R, Fonda C, Gasparotti R, Villari N. Diffusion-weighted MR of the brain: Methodology and clinical application. Radiol Med 2005; 109: 155-97.

15. Hart LA, Sibai BM. Seizures in pregnancy: epilepsy, eclampsia, and stroke. Semin Perinatol 2013; 37: 207-24. [CrossRef]

16. Ray WZ, Moran CJ, Derdeyn CP, Diringer MN, Dacey RG Jr, Zipfel GJ. Near-complete resolution of angiographic cerebral vasospasm after extreme elevation of mean arterial pressure: Case Report Surg Neurol 2009; 72: 347-53.

17. Vollmar B, Menger MD. Microcirculatory dysfunction in acute pancreatitis. A new concept of pathogenesis involving vasomotionassociated arteriolar constriction and dilation. Pancreatology 2003; 3: 181-90. [CrossRef]

18. Immink RV, Truijen J, Secher NH, Van Lieshout JJ. Transient influence of end-tidal carbon dioxide tension on the postural restraint in cerebral perfusion. J Appl Physiol 2009; 107: 816-23. [CrossRef]
19. Schwartz RB, Feske SK, Polak JF, DeGirolami U, Iaia A, Beckner $\mathrm{KM}$, et al. Preeclampsia-eclampsia: clinical and neuroradiographic correlates and insight into the pathogenesis of hypertensive encephalopathy. Radiology 2000; 217: 371-6. [CrossRef]

20. Bhagavati S, Chum F, Choi J. Hypertensive encephalopathy presenting with isolated brain stem and cerebellar edema. J Neuroimaging 2008; 18: 454-6. [CrossRef]

21. Yoshino H, Sakurai T, Oizumi XS, Akisaki T, Wang X, Yokono K, et al. Dilation of perforating arteries in rat brain in response to systemic hypotension is more sensitive and pronounced than that of pial arterioles: Simultaneous visualization of perforating and cortical vessels by in-vivo microangiography. Microvasc Res 2009; 77: 230-3. [CrossRef]

22. Minn AY, Fisher PG, Barnes PD, Dahl GV. A syndrome of irreversible leukoencephalopathy following pediatric allogeneic bone marrow transplantation. Pediatr Blood Cancer 2007; 48: 213-7. [CrossRef]

23. Friese S, Fetter M, Küker W. Extensive brainstem oedema in eclampsia: Diffusion-weighted MRI may indicate a favourable prognosis. J Neurol 2000; 247: 465-6. [CrossRef]

24. Hellmeyer L, Iwinska-Zelder J, Gerken L, Kühnert M, Schmidt $\mathrm{S}$. Changes in MR images in pre-eclampsia and eclampsia. Z Geburtshilfe Neonatol 2009; 213: 27-31. [CrossRef]

25. Keswani SC, Wityk R. Don't throw in the towel! A case of reversible coma. J Neurol Neurosurg Psychiatry 2002; 73: 83-4. [CrossRef]

26. Sibai BM. Management of late preterm and early-term pregnancies complicated by mild gestational hypertension/pre-eclampsia. Semin Perinatol 2011; 35: 292-6. [CrossRef]

27. Solinas C, Briellmann RS, Harvey AS, Mitchell LA, Berkovic SF. Hypertensive encephalopathy. Antecedent to hippocampal sclerosis and temporal lobe epilepsy? Neurology 2003; 60: 1534-6. [CrossRef]

28. Striano P, Striano S, Tortora F, De Robertis E, Palumbo D, Elefante A, Servillo G. Clinical spectrum and critical care management of posterior reversible encephalopathy syndrome (PRES). Med Sci Monit 2005; 11: 549-53.

29. Casey SO, McKinney A, Teksam M, Liu H, Truwit CL. CT perfusion imaging in the management of posterior reversible encephalopathy. Neuroradiology 2004; 46: 272-6. [CrossRef]

30. Finsterer J, Schlager T, Kopsa W, Wild E. Nitroglycerin aggravated pre-eclamptic posterior reversible encephalopathy syndrome. Neurology 2003; 61: 715-6. [CrossRef]

31. Harkany T, Dijkstra IM, Oosterink BJ, Horvath KM, Abraham I, Keijser J, et al. Amyloid precursor protein expression and serotonergic sprouting following excitotoxic lesion of the rat magnocellular nucleus basalis: Neuroprotection by $\mathrm{Ca}(2+)$ antagonist nimodipine. Neuroscience 2000; 101: 101-14. [CrossRef]

32. Sekine T, Ikeda K, Hirayama T, Suzuki A, Iwasaki Y. Transient splenial lesion after recovery of cerebral vasoconstriction and posterior reversible encephalopathy syndrome: A case report of eclampsia. Intern Med 2012; 51: 1407-11. [CrossRef]

33. Goyagi T, Horiguchi T, Nishikawa T, Tobe Y, Masaki Y. Neuroprotective effects of selective $\beta-1$ adrenoceptor antagonists, landiolol and esmolol, on transient forebrain ischemia in rats; a dose-response study. Brain Res 2012; 1461: 96-101. [CrossRef]

34. Altman D, Carroli G, Duley L, Farrell B, Moodley J, Neilson J, et al. Do women with pre-eclampsia, and their babies, benefit from magnesium sulphate? The Magpie Trial: A randomised placebocontrolled trial. Lancet 2002; 359: 1877-90. [CrossRef]

35. Demirel I, Ozer AB, Bayar MK, Kavak SB. Anesthesia and Intensive Care Management in a Pregnant Woman with PRES: A Case Report. Case Rep Anesthesiol 2012; 5: 1-5. [CrossRef]

36. Parviainen I, Uusaro A, Kälviäinen R, Mervaala E, Ruokonen E. Propofol in the treatment of refractory status epilepticus. Intensive Care Med 2006; 32: 1075-9. [CrossRef] 